\title{
Geology of the Femern Bælt area between Denmark and Germany
}

\author{
Emma Sheldon, Peter Gravesen and Henrik Nøhr-Hansen
}

Geological and geotechnical investigations in the Femern Bælt area were undertaken from 1995 to 2010 (Rambøll Arup JV 2011) in preparation for the fixed link between Lolland in Denmark and Fehmarn in Germany. As a result, new data have been acquired on the stratigraphy and distribution of the deposits and the major structures and tectonic influence on the layers close to the surface. Previous investigations of Cretaceous-Palaeogene deposits on southern Lolland (Fig. 1) were limited due to lack of outcrops and borehole data. Two deep boreholes and geophysical surveys (19521953) revealed: (1) the presence of a salt diapir at Rødbyhavn, (2) upper Maastrichtian chalk 29-143 m below Quaternary deposits and (3) an erosional window in the Palaeogene cover. Boreholes to the east of Rødbyhavn (1992-1994) revealed the sediment distribution on southern Lolland and showed that Cretaceous and Palaeogene deposits are cut by several NW-SE-orientated faults. This paper presents a summary of lithostratigraphic and biostratigraphic investigations and a brief description of the geological development in the area.

\section{Methods}

A multidisciplinary biostratigraphic study was undertaken of 170 samples from 46 wells drilled in 2009-2010 in the Femern Bælt region. The wells were drilled to depths of 50$100 \mathrm{~m}$ and were fully cored in the pre-Quaternary deposits.

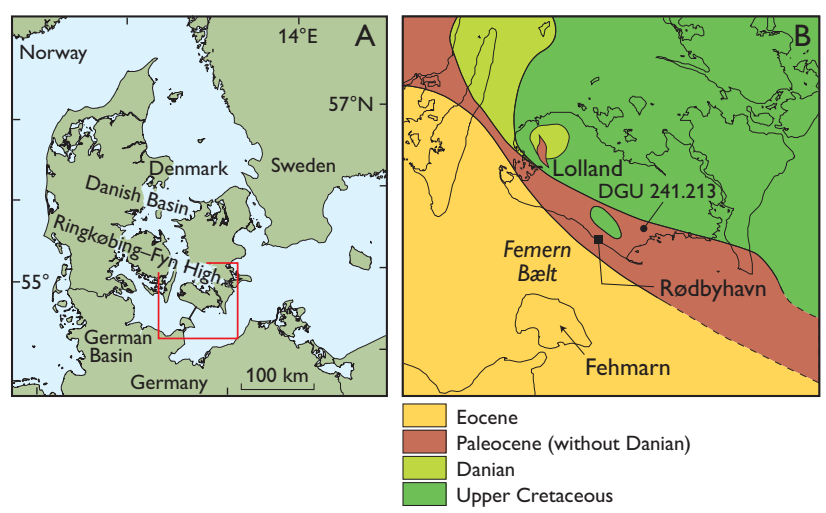

Fig. 1. A: Map of Denmark and northern Germany showing the proposed location of the fixed link across the Femern Bælt. B: Geological map of the Femern Bælt region (after Håkansson \& Pedersen 1992).
One to ten samples from each well were selected for biostratigraphic analysis by Rambøll Arup JV. Nannofossil analysis was carried out on all samples. Supplementary analyses were carried out using microfossils and dinoflagellate cysts (dinocysts) when necessary. Nannofossils are particularly useful for dating chalk and clay, microfossils for chalk, sand and clay and dinocysts for clay. The use of three fossil groups allowed for well-constrained and reliable dating and formation identification (Sheldon \& Nøhr-Hansen 2010). In addition, 13 samples from DGU core 241.213, a water well from 2011 on Lolland, were analysed.

\section{Biostratigraphy and lithostratigraphy}

A chronostratigraphic, biostratigraphic and lithostratigraphic correlation is presented in Fig. 2. The lithologies and selected marker fossils reported in this article are as follows (see also Fig. 3):

Tor Formation equivalent (Campanian-Maastrichtian) - The Tor Formation of the North Sea was originally described by Deegan \& Scull (1977) as homogeneous white or grey chalk, bioturbated pelagic chalk, laminated chalk and redeposited chalk. The Femern Bælt area chalk is slightly indurated, with $<5 \%$ flint nodules.

Biostratigraphic marker fossils: Tranolithus orionatus, Reinhardtites levis, Nephrolithus frequens, Arkhangelskiella maastrichtiana, Eiffellithus turriseiffelii, Prediscosphaera spinosa, Cribrosphaerella daniae (nannofossils), Bolivinoides laevigatus, Praebulimina levis, Reusella szajnochae szajnochae, Bolivina incrassata, Stensioeina pommerana (foraminifera), Cannosphaeropsis utinensis, Montanarocysta aemiliana and Xenascus wetzelii (dinocysts).

Danian limestone (lower-middle Danian) - comprises fossiliferous limestone, rich in echinoderm, bryozoan and bivalve fragments and is recognised as a thin layer on Lolland (DGU core 241.213).

Biostratigraphic marker fossils: Prinsius tenuiculus, Prinsius dimorphosus, Chiasmolithus danicus, Cruciplacolithus tenuis, Neochiastozygus modestus (nannofossils), Eoglobige- 


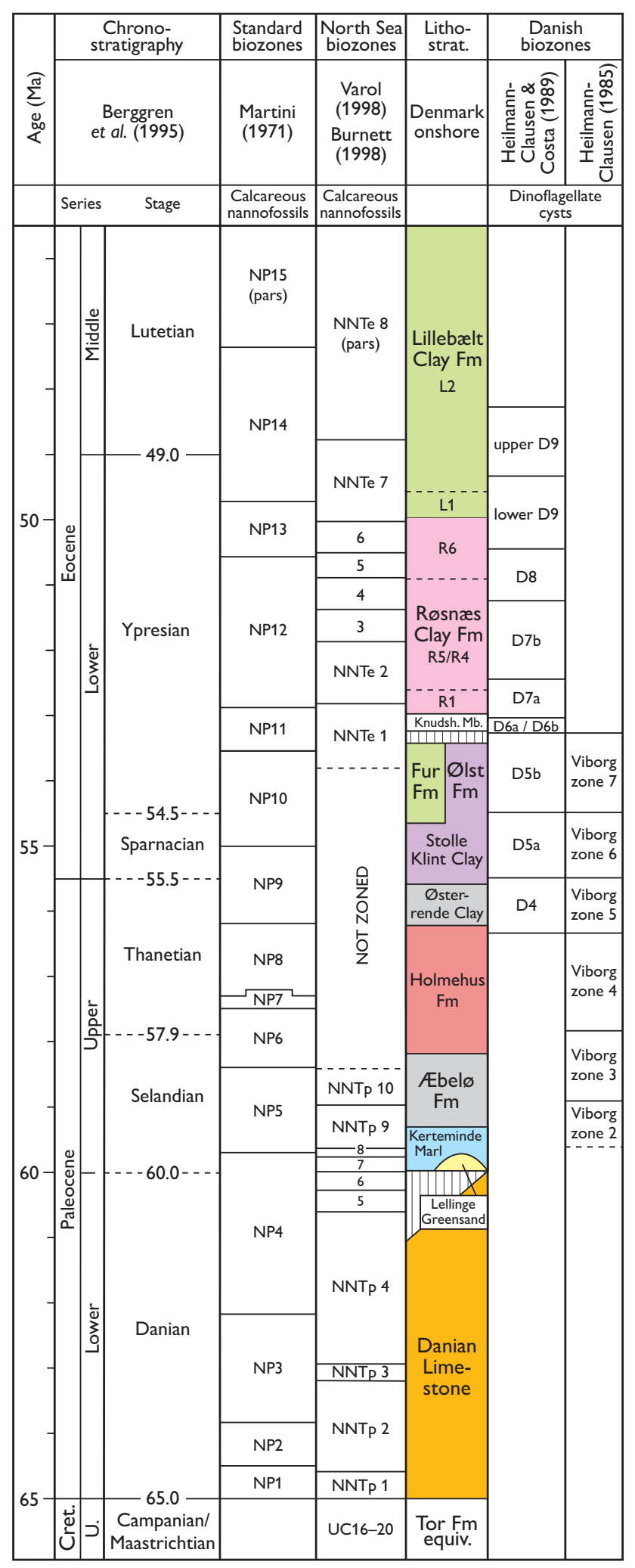

Fig. 2. Chrono-, bio- and lithostratigraphy of the Campanian-Eocene in Denmark. Note, not all formations have been found in the investigated area. rina edita, Globoconusa daubjergensis and Cibicidoides succedens (foraminifera).

Lellinge Greensand (lower Selandian) - In DGU core 241.213, Lellinge Greensand (originally described by Gry 1935) comprises olive-grey, glauconitic, sandy, hard limestone intercalated with fine-grained clay with brown phosphate nodules and pyrite. Lellinge Greensand is also encountered in a number of Femern Bælt boreholes.

Biostratigraphic marker fossils: common Neochiastozygus perfectus and Prinsius martinii (nannofossils), Globanomalina ehrenbergi, Bulimina trigonalis (common) and Gavelinella danica (foraminifera) with reworked Danian and Upper Cretaceous nanno- and microfossils (Danian limestone and Tor Formation equivalent) and macrofossil debris.

Abelø Formation (middle Selandian) - The Æbelø Formation (Heilmann-Clausen et al. 1985) comprises slightly calcareous to non-calcareous, silty - very silty, grey clay.

Biostratigraphic marker fossils: Chiasmolithus edentulus, Chiasmolithus eograndis (nannofossils), Isabelidinium? viborgense and Palaeoperidinium pyrophorum (dinocysts).

Holmehus Formation (Selandian-Thanetian) - The Holmehus Formation (Heilmann-Clausen et al. 1985) consists of non-calcareous, greenish, brownish and reddish, very finegrained clay with minor sand and phosphatic or sideritic concretions.

Biostratigraphic marker fossils: Transversopontis pulcheroides, Zygodiscus adamas, Neococcolithes protenus (nannofossils), Cyclammina amplectens, (foraminifera), Alisocysta sp. 1 Heilmann-Clausen 1985 and Cerodinium medcalfii (dinocysts).

Ølst Formation (lower Ypresian) - The Ølst Formation (Heilmann-Clausen et al. 1985) is a grey to almost black, sandy, silty and mainly non-calcareous clay, interbedded with layers and laminae of black or grey volcanic ash.

Biostratigraphic marker fossils: Sphenolithus editus, Tribrachiatus orthostylus, Lophodolithus nascens (nannofossils), Fenestrella antiqua, Coscinodiscus morsianus moelleri, Triceratium spp. (diatoms), Apectodinium hyperacanthum and Deflandrea oebisfeldensis (dinocysts).

Røsnas Clay Formation (middle Ypresian) - The Røsnæs Clay Formation (Dinesen et al. 1977; Heilmann-Clausen et al. 1985) comprises red, brown and yellow-brown, very finegrained, plastic marine clay with glauconitic beds at the base and greenish volcanic ash layers throughout. 
Biostratigraphic marker fossils: Discoaster kuepperi, Imperiaster obscurus, Toweius occulatus, Rhabdosphaera pinguis, Discoaster lodoensis (nannofossils), Turrilina brevispira, Clavulina anglica, Pseudohastigerina wilcoxensis, Gaudryina biltermanni, Subbotina patagonica (foraminifera), Dracodinium? condylos, Ochetodinium romanum, Wetzeliella astra, Dracodinium solidum, Eatonicysta ursulae and Dracodinium varielongitudum (dinocysts).

Lillebalt Clay Formation (upper Ypresian - lower Lutetian) - The Lillebælt Clay Formation is a green-grey, non-calcareous, very fine-grained plastic clay containing concretions, with red-brown clay beds in the lower part (Dinesen $e t$ al. 1977; Heilmann-Clausen et al. 1985).

Biostratigraphic marker fossils: Vaginulinopsis decoratus (foraminifera), Membranilarnacia compressa, Charlesdowniea columna and Eatonicysta furensis (dinocysts).

\section{Geological development}

Lolland is located to the south of the Ringkøbing-Fyn High, in the German Basin. During the Late Cretaceaous, fully marine conditions characterised the Danish area including the northern highs and chalk of the Campanian - upper Maastrichtian Tor Formation equivalent was deposited. Danian limestone and Lellinge Greensand have recently been found in situ on southern Lolland and are documented here for the first time. The Danian limestone is $c .2 \mathrm{~m}$ thick. Danian nannofosssils and microfossils are also found in small limestone clasts within the Selandian deposits, indicating that Danian sediments were eroded and partially redeposited at the end of the Danian and probably also in the earliest Selandian.

The lower Selandian glauconitic and conglomeratic deposits of the Lellinge Greensand rest on Danian sediments on Sjælland, especially in the Copenhagen area (Stouge et al. 2000). Clasts, microfossils and nannofossils from the lower Selandian also indicate deposits from the Lellinge Greensand in the Femern Bælt area. The Lellinge Greensand is at least 12-13 m thick; the top is eroded and covered by Quaternary deposits. In DGU core 241.213 the Lellinge Greensand is found $138 \mathrm{~m}$ below ground surface. The encountered glauconitic deposits from the Lelllinge Greensand rest on Danian limestone in a small subsided fault block, demonstrating that the lowermost Selandian was probably deposited in the area and subsequently eroded.

The early-middle Paleocene sea was more restricted than in the Cretaceous and several highs bordered the marine area (Clausen \& Huuse 2002). The Danian was dominated by erosion, rising sea level characterised the early Selandian and erosion dominated again during the late early Selandian. These two erosional episodes may have resulted in sediment removal, but it is also possible that the area was subaerial during part of the Danian-Selandian. Continued erosion or nondeposition characterised the upper Selandian and therefore deposits from the Kerteminde Marl Formation (up to $100 \mathrm{~m}$ thick on Sjælland) are not found in the area, probably due to uplift during this time.

Clastic marine sedimentation resumed during the upper Selandian sea-level rise, and the North Sea, Denmark

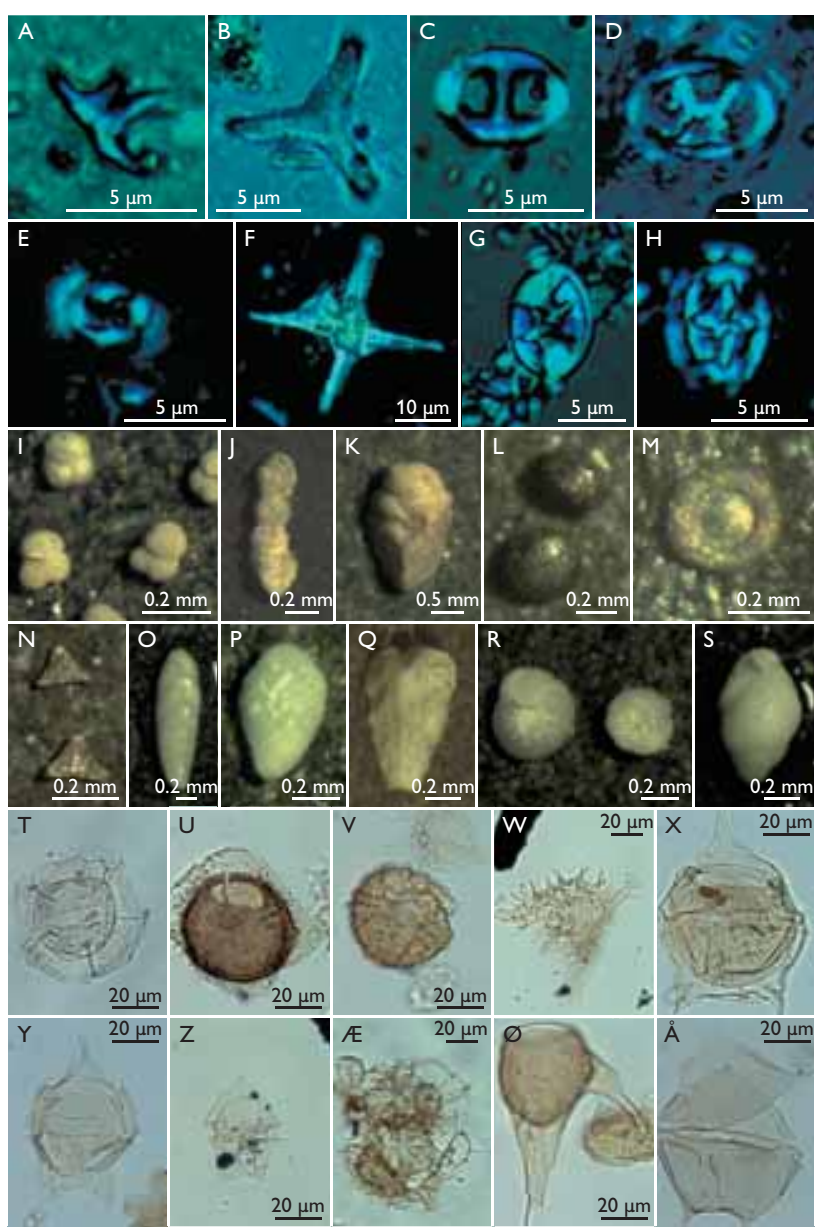

Fig. 3. Selected important nannofossils (A-H), microfossils (I-S) and dinocysts (T-Å). A: Discoaster kuepperi, B: Tribrachiatus orthostylus, C: Lophodolithus nascens, D: Neococcolithes protenus, E: Toweius occulatus, F: Imperiaster obscurus, G: Eiffellithus turriseiffelii, $\mathbf{H}$ : Prediscosphaera spinosa, I: Subbotina patagonica, J: Clavulina anglica, K: Gaudryina hiltermanni, L: Fenestrella antiqua, M: Coscinodiscus morsianus moelleri, $\mathbf{N}$ : Triceratium spp., O: Bolivina incrassata, P: Bolivinoides laevigatus, Q: Reusella szajnochae szajnochae, R: Stensioeina pommerana, S: Praebulimina levis, T: Eatonicysta furensis, U: Dracodinium? condylos, V: Ochetodinium romanum, W: Apectodinium hyperacanthum, X: Deflandrea oebisfeldensis, Y: Cerodinium medcalfii, Z: Isabelidinium? viborgense, Æ: Cannosphaeropsis utinensis, Ø: Xenascus wetzelii, Å: Palaeoperidinium pyrophorum. 


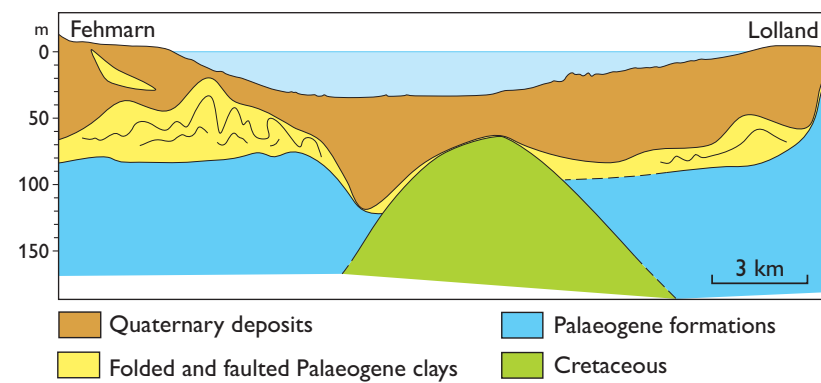

Fig. 4. Simplified geological cross-section across the Femern Bælt. The folding shown in the Palaeogene clay is for illustrative purposes only; the real nature of the disturbance (folding and faulting) is much more intense and complicated than shown (modified after Rambøll Arup JV 2011).

and the German Basin formed a partly enclosed shelf area. The remainder of the Palaeogene (Æbelø, Holmehus, Ølst, Røsnæs Clay and Lillebælt Clay) formations mainly consist of fine-grained, plastic clay but there were many lithological shifts during this time. Deposition occurred in a relatively deep marine basin, although proximal to the shore. The changes in depositional conditions were related to changing circulation patterns in the North Sea and shifts in clay mineral provenance and periods of regression and non-deposition also occurred (Heilmann-Clausen et al. 1985). Intense volcanic activity caused by the opening of the North Atlantic resulted in ash deposition during the late Paleocene and Eocene.

Quaternary glacial activity eroded, faulted and folded the Palaeogene sediments resulting in their present distribution (Fig. 4). The new biostratigraphic studies indicate that the Røsnæs Clay Formation is strongly folded with repeated stratigraphy, indicating movements along faults. The youngest formation in the area, the Lillebælt Clay Formation, occurs only as floes in the glacial sediments. On land, the Palaeogene clay seems to be undisturbed towards the north whereas disturbances increase towards the south.

\section{Conclusions}

The recent biostratigraphic study has provided important information about the pre-Quaternary deposits under the $c$. $18 \mathrm{~km}$ wide Femern Bælt, imperative to planning the construction of the Femern Bælt fixed link. The CretaceousPalaeogene Tor Formation equivalent, Danian limestone, Lellinge Greensand, Æbelø, Holmehus, Ølst, Røsnæs and Lillebælt Formations have been identified in multiple boreholes using multidisciplinary biostratigraphy. This information, coupled with physical rock properties (Rambøll Arup
JV 2011) allows a geological cross-section of the Femern Bælt to be established and demonstrates the complex nature of the depositional and structural history of the area. In addition, in situ Danian limestone has been discovered for the first time, along with Lellinge Greensand on Lolland in DGU core 241.213 . The new data from $>500 \mathrm{~m}$ fully cored boreholes provide an excellent basis for future detailed biostratigraphic, sedimentological and basin analysis of the Palaeogene deposits in the area.

\section{References}

Berggren, W.A., Kent, D.V., Swischer III, C.C. \& Aubry, M.-P. 1995: A revised Cenozoic geochronology and chronostratigraphy. In: Berggren, W.A. et al. (eds): Geochronology, time scale and global stratigraphic correlation. Society for Sedimentary Geology (SEPM) Special Publication 54, 129-212.

Burnett, J.A. 1998: Upper Cretaceous. In: Bown, P.R. (ed.): Calcareous nannofossil biostratigraphy. British Micropalaeontological Society Series, 132-199.

Clausen, O.R. \& Huuse, M. 2002: Mid-Paleocene palaeogeograhpy of the Danish area. Bulletin of the Geologocal Society of Denmark 49, 171-186.

Deegan, C.E. \& Scull, B.J. 1977: A standard lithostratigraphical nomenclature for the central and northern North Sea. The Institute of Geological Sciences Report 77/25, 36 pp.

Dinesen, A., Michelsen, O. \& Lieberkind, K. 1977: A survey of the Paleocene and Eocene deposits of Jylland and Fyn. Danmarks Geologiske Undersøgelse Serie B1, 15 pp.

Gry, H. 1935: Petrology of the Paleocene sedimentary rocks of Denmark. Danmarks Geologiske Undersøgelse II. Række 61, 180 pp.

Heilmann-Clausen, C. 1985: Dinoflagellate stratigraphy of the uppermost Danian to Ypresian in the Viborg 1 borehole, central Jylland, Denmark. Danmarks Geologiske Undersøgelse Serie A7, 69 pp.

Heilmann-Clausen, C., Nielsen, O.B. \& Gersner, F. 1985: Lithostratigraphy and depositional environments in the Upper Paleocene and Eocene of Denmark. Bulletin of the Geological Society of Denmark 33, 287-323.

Heilmann-Clausen, C. \& Costa, L.I. 1989: Dinoflagellate Zonation of the Uppermost Paleocene? to lower Miocene in the Würsterheide Research Well, northwest Germany. Geologisches Jahrbuch A111, 431-521.

Håkansson, E., \& Pedersen, S.S. 1992: Kort over den danske undergrund. København: Varv (map sheet).

Martini, E. 1971: Standard Tertiary and Quaternary calcareous nannoplankton zonation. In: Farinacci, A. (ed.): Proceedings of the Second Planktonic Conference Roma. Edizioni Tecnoscienza, Rome 2, 739-785.

Rambøll Arup JV 2011: Summary of geological conditions. Geotechnical Data Report 01.3-002, 53 pp. Virum: Femern A/S.

Sheldon, E. \& Nøhr-Hansen, H. 2010: Fehmarn Belt fixed link pre-Quaternary biostratigraphy - a final status report for Rambøll Arup Joint Venture. Danmarks og Grønlands Geologiske Undersøgelse Rapport 2010/134, 53 pp.

Stouge, S., Hjortkjær, B.F., Rasmussen, J.A., Roncaglia, L. \& Sheldon, E. 2000: Micro- and nannofossil biostratigraphy across the Danian/Selandian (Paleocene) stage boundary at Gemmas Allé, Copenhagen, Denmark. GFF 122, 161-162. Stockholm: Geological Society of Sweden.

Varol, O. 1998: Palaeogene. In: Bown, P.R. (ed.): Calcareous Nannofossil Biostratigraphy. British Micropalaeontological Society Series, 200-224.

\footnotetext{
Authors' address

Geological Survey of Denmark and Greenland, ØsterVoldgade 10,DK-1350 Copenhagen K, Denmark. E-mail: es@geus.dk
} 